\title{
Financial collateral: the legal framework of the European Union and UNIDROIT compared
}

\section{Thomas Keijser*, Maria Kyrkousi ${ }^{\dagger}$, and Andreas Bakanos*}

\section{Introduction}

Financial collateral arrangements play a pivotal role in today's financial markets. The European Union's (EU) Directive 2002/47/EC on financial collateral arrangements, as amended (Financial Collateral Directive or FCD) ${ }^{1}$ and Chapter V of the Unidroit Convention on Substantive Rules for Intermediated Securities (Geneva Securities Convention or GSC) ${ }^{2}$ both contain detailed rules in relation to such arrangements. The FCD and Chapter V of the GSC largely pursue the harmonization of the same key issues regarding financial collateral arrangements. Both instruments take a novel approach with respect to collateral provided by way of either a title transfer or the grant of a security interest. ${ }^{3}$ They prohibit the

* Thomas Keijser, senior researcher, Business and Law Research Centre, Radboud University, P.O. Box 9049, 6500 KK, Nijmegen, Netherlands; attorney-at-law (advocaat), Nijmegen, Netherlands. Tel: +31 (0)88 0440880. Email: t.keijser@jur.ru.nl. As a senior officer at the International Institute for the Unification of Private Law (UNIDROIT), Keijser was responsible for the UNIDROIT Convention on Substantive Rules for Intermediated Securities. He is also visiting faculty at the International Hellenic University in Thessaloniki, Greece, where he teaches in the context of the LLM in Transnational and European Commercial Law and Alternative Dispute Resolution.

$\dagger$ Maria Kyrkousi, graduate in Transnational and European Commercial Law and Alternative Dispute Resolution, International Hellenic University, Thessaloniki, Greece. Tel: +44 (0)78 40879793. Email: m.kyrkousi@ihu.edu.gr.

* Andreas Bakanos, graduate in Transnational and European Commercial Law and Alternative Dispute Resolution, International Hellenic University, Thessaloniki, Greece. Tel: +30697 2700337. Email: a.bakanos@ihu.edu.gr.

The authors are grateful to Professor Hideki Kanda (University of Tokyo, Japan) and Professor Marcel Peeters (University of Amsterdam, Netherlands) for their constructive comments on an earlier version of this article, and to Professor Henri de Waele (Radboud University Nijmegen, Netherlands) for advice on issues of European law. The authors are fully responsible for this article's final content.

1 Directive 2002/47/EC on financial collateral arrangements [2002] OJ L168/43, as amended by Directive 2009/44/EC [2009] OJ L146/37 and Directive 2014/59/EU [2014] OJ L173/190.

2 UnIDRoIT Convention on Substantive Rules for Intermediated Securities <http://www.unidroit. org/english/conventions/2009intermediatedsecurities/convention.pdf > accessed 31 May 2014. It was adopted in 2009.

3 For this distinction, see FCD (n 1) art 2(1)(a)-(c) and GSC (n 2) art 31(3)(a)-(c).

(C) The Author (2014). Published by Oxford University Press on behalf of UNIDROIT. All rights reserved. For Permissions, please email journals.permissions@oup.com 
re-characterization of title transfers as grants of security interests; ${ }^{4}$ provide for a collateral taker's 'right of use' - that is, a general right of disposal in relation to collateral provided by way of a security interest; ${ }^{5}$ ensure swift enforcement without impediments, including by way of close-out netting; ${ }^{6}$ and provide a level of protection in insolvency. ${ }^{7}$ The FCD and the GSC relax, modify, or disapply 'traditional' features of secured transactions and insolvency law. Whereas the position of collateral takers is generally enhanced, the protection of collateral providers and other creditors is weakened. ${ }^{8}$ Arguments for this new approach include the special nature of financial collateral, which is often highly liquid and subject to continuous fluctuations in value, as well as expectations of enhanced liquidity across the financial markets, cheaper credit, and a reduction of systemic risk through the mitigation of the 'domino effects' of individual insolvencies.'

This article provides a technically oriented comparison of the substantive law provisions of the FCD and Chapter V of the GSC in order to determine to what extent these legal instruments are compatible. ${ }^{10}$ In light of profound changes to the financial collateral landscape as a result of the recent financial crisis, it will also pay attention to a (revived) debate on (regulatory) limitations to the liberal legal regime of the FCD and the GSC, including checks in regard to personal scope, the collateral taker's right of use, and enforcement. It will not examine other postcrisis developments, such as those relating to changes both in the demand for financial collateral (including changes due to an increase in secured lending, new

4 FCD (n 1) art 6; GSC (n 2) art 32.

5 FCD (n 1) art 5; GSC (n 2) art 34.

6 FCD (n 1) arts 4 and 7; GSC (n 2) arts 33 and 35.

7 FCD (n 1) art 8; GSC (n 2) arts 36 and 37.

8 GSC (n 2) art 31(2) reflects this collateral taker-oriented approach; see also Hideki Kanda and others, Official Commentary on the UNIDROIT Convention on Substantive Rules for Intermediated Securities (Oxford University Press 2012) V-2, 31-1, 31-17-31-18. Changmin Chun, Cross-Border Transactions of Intermediated Securities: A Comparative Analysis in Substantive Law and Private International Law (Springer 2012) 101 points to possible negative consequences of this approach for the collateral provider and its creditors. On balancing the interests of collateral taker and provider, see also Louise Gullifer, 'What Should We Do about Financial Collateral?' (2012) 65 Current Legal Problems 377-410; Thomas Keijser, Financial Collateral Arrangements: The European Collateral Directive Considered from a Property and Insolvency Law Perspective (Kluwer 2006); Thomas Keijser, 'A Need for a Change: The Undesirable Consequences of the Settlement Finality Directive and the Collateral Directive in the Field of Property and Insolvency Law, in Particular for Small- and Medium-Sized Enterprises' (2006) 14(2) Zeitschrift für Europäisches Privatrecht 308-25. It should be noted that the same party may be collateral provider and collateral taker from time to time.

9 Gullifer (n 8) 379-81; Thomas Keijser, Guy Morton and Marcel Peeters, 'Financial Collateral: From Private to Regulatory Law Reform' in Thomas Keijser (ed), Transnational Securities Law

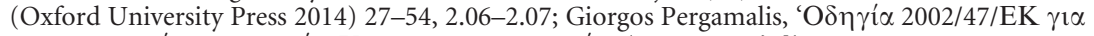

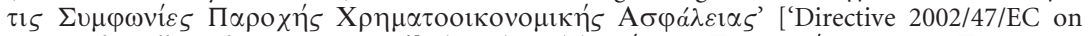

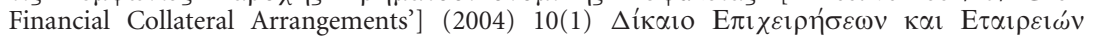
33-46, 33-4.

10 For a brief comparison of a draft of the GSC (n 2) and the FCD (n 1) before its amendment in 2009, see Thomas Keijser and Han Keijser, Financiëlezekerheidsovereenkomsten [Financial Collateral Agreements] (Kluwer 2008) 3. 
regulatory margin requirements regarding derivatives, and revised capital adequacy requirements) and in the supply thereof (including changes in light of the issuance of new securities, collateral transformation, and technological innovation). ${ }^{11}$ Conflict of laws issues in relation to financial collateral will also not be discussed. $^{12}$

The following specific topics will be examined: personal scope (section II); types of collateral covered (section III); types of relevant obligations covered (section IV); the right of use (section V); enforcement, with a special focus on close-out netting (section VI); the protection of margin maintenance and substitution arrangements, in particular in insolvency (section VII); and the treatment of collateral arrangements after the commencement of insolvency proceedings ${ }^{13}$ (section VIII). In these sections, in light of the circumstance that the FCD was an important source of inspiration in the drafting of Chapter V of the GSC, the FCD is taken as the basis of the analysis against which the GSC is compared, so as to identify similarities and differences between the two legal instruments.

Some general differences should be mentioned at the outset. Content-wise, whereas the FCD regulates only financial collateral arrangements, the GSC covers a much wider range of issues relating to the functioning of an intermediated securities system, including aspects of holding, transfer, insolvency, and the integrity of the system as a whole. In regard to territorial scope, whereas the FCD applies to Member States of the EU, the GSC, upon entry into force, applies in relation to Contracting States anywhere in the world. Whereas the FCD is currently in force and implemented, the GSC is not, while nonetheless serving as a benchmark of international best practice. ${ }^{14}$ In addition, it should be noted that Chapter V of the GSC is optional as a whole. This optional character gives Contracting States the flexibility to respond to public policy issues especially in connection with consumer protection and insolvency. ${ }^{15}$

11 See, eg, Jorge Cruz Lopez, Royce Mendes and Harri Vikstedt, 'The Market for Collateral: The Potential Impact of Financial Regulation' (June 2013) Financial System Review (Bank of Canada) 45-53; David Murphy, 'The Rising Risks and Roles of Financial Collateral' (2014) 29(1) Butterworths Journal of International Banking and Financial Law 3-8; Jo van de Velde, 'The Evolving Role of Collateral in International Capital Markets' (2012-13) 5(3) Journal of Securities Operations and Custody 218-31.

12 See, in particular, FCD (n 1) art 9 and the Convention on the Law Applicable to Certain Rights in Respect of Securities Held with an Intermediary of the Hague Conference on Private International Law (2006) <http://www.hcch.net/index_en.php?act=conventions.text\&cid=72> accessed 9 July 2014.

13 For the sake of simplicity, this article uses the term 'insolvency proceedings', which is intended to encompass the reorganization and winding-up or liquidation components that are also reflected in the definitions of 'winding-up proceedings' and 'reorganisation measures' (FCD (n 1) art 2(1)(j) and (k)) and 'insolvency proceeding' (GSC (n 2) art 1(h)).

14 The GSC (n 2) has only been signed by Bangladesh. See < http://www.unidroit.org/status> accessed 25 June 2014.

15 Kanda and others (n 8) 38-7. 


\section{Personal scope}

\section{Financial Collateral Directive}

The personal scope of the FCD is determined in Article 1(2) and (3), which essentially provides Member States with two options. The first option, which applies by default, envisages a broad personal scope. This option applies where at least one of the parties is a financial market participant falling within one of the following categories: (i) public authorities, including those public sector bodies that participate in the management of public debt or are authorized to hold accounts for customers; (ii) central banks, the European Central Bank (ECB), the Bank for International Settlements (BIS), multilateral development banks (MDBs), the International Monetary Fund (IMF), and the European Investment Bank (EIB); (iii) financial institutions subject to prudential supervision, including credit institutions, investment firms, financial institutions, insurance undertakings, undertakings for collective investment in transferable securities, and management companies; as well as (iv) central counterparties, settlement agents, or clearing houses, including similar institutions acting in the futures, options, and derivatives markets, and non-natural persons acting in a trust or representative capacity for one or more persons that includes bondholders or holders of other forms of securitized debt or any of the institutions referred to under points (i)-(iv) ${ }^{16}$ The other party can be either a financial market participant referred to under points (i)-(iv) or any other non-natural person, such as a 'non-financial' enterprise or an unincorporated firm or partnership. ${ }^{17}$ This option thus excludes natural persons but includes entities without legal personality. ${ }^{18}$

The second option is to limit the personal scope of the FCD by making a declaration under Article 1(3). This provision allows Member States to limit the personal scope of the Directive to the financial market participants referred to earlier under points (i)-(iv) only.

It is clear from both options that the FCD does not apply to financial collateral arrangements in two cases: first, when a party is a natural person and, second, where both parties belong to one of the categories of Article 1(2)(e), such as non-financial enterprises, unincorporated firms, and partnerships. ${ }^{19}$ The FCD may nonetheless apply to micro-, small-, and medium-sized entities under both the aforementioned options. The category of non-natural persons acting in a trust or representative capacity for other persons (to which the FCD applies under both options) may include minor entities, but these will generally be specialized

16 FCD (n 1) art 1(2)(a)-(d).

17 Ibid art 1(2)(e).

18 Felice Bonfanti, Il pegno fra codice civile e legislazione speciale: l'impatto della nuova disciplina dei contratti di garanzia finanziaria [The Pledge between the Civil Code and Special Legislation: The Impact of the New Discipline of Financial Collateral Agreements] PhD thesis, Università degli Studi di Ferrara (2009) 76-81.

19 Ibid 77-8; Keijser, Financial Collateral Arrangements (n 8) II.8.2.4. 
financial services providers. ${ }^{20}$ In particular, the inclusion of micro-, small-, and medium-sized entities lacking expertise in the financial markets raises concerns.

Arguments in favour of a broad personal scope include facilitating access to low-cost credit for businesses with no or low credit rating and ensuring an efficient and predictable regime for financial collateral arrangements. However, the 'opt-out' in Article 1(3) of the FCD was introduced to accommodate concerns regarding situations where there is no equal bargaining power between the parties to financial collateral arrangements (and the unconscionable transactions that might result) and the risk of creating special privileges for collateral takers, in particular, when these are major financial institutions, and consequent incursions on the fundamental insolvency principle of the equality of creditors (paritas creditorum). Member States can thus weigh these considerations and decide whether or not to opt for a broader personal scope. ${ }^{21}$ In the aftermath of the financial crisis, Louise Gullifer argues for limiting the scope of the FCD to wholesale financial market participants. ${ }^{22}$

\section{Chapter $V$ of the Geneva Securities Convention}

The GSC also takes a broad personal scope as a starting point. While it defines the terms 'collateral provider' and 'collateral taker' as a person granting or being granted an interest in intermediated securities under a collateral agreement, ${ }^{23}$ the GSC contains no provision that lists or otherwise identifies the entities or persons that may qualify as collateral providers and takers. Thus, as a matter of principle, Chapter V of the GSC applies not only to financial market participants, such as banks, pension funds, and insurance undertakings, but also to 'nonfinancial' enterprises, entities without legal personality, and even to natural persons. ${ }^{24}$

On the basis of considerations comparable to those in favour of a limited scope of the FCD (section II.1 in this article), Article 38(2)(a) of the GSC contains an opt-out clause that makes it possible to restrict the personal scope of Chapter $\mathrm{V}^{25}$

20 Keijser, Financial Collateral Arrangements (n 8) II.6.3.

21 For arguments pro and con, see European Commission, Proposed Directive on Financial Collateral Arrangements: Frequently Asked Questions MEMO/01/108 (30 March 2001) 3 <http://europa.eu/ rapid/press-release_MEMO-01-108_en.htm> accessed 26 May 2014; Keijser, Financial Collateral Arrangements (n 8) II.6, VI.3.2, VI.4.2; Klaus Löber, 'Der Entwurf einer Richtlinie für Finanzsicherheiten' ['The Draft Financial Collateral Directive'] (2001) 3 Zeitschrift für Bankund Kapitalmarktrecht 118-24, 120; Klaus Löber, 'The German Implementation of the EC Directive on Financial Collateral Arrangements' (2005) 20(2) Journal of International Banking Law and Regulation 72-8, 73-4; Klaus Löber and Ewa Klima, 'The Implementation of Directive 2002/47 on Financial Collateral Arrangements' (2006) 21(4) Journal of International Banking Law and Regulation 203-12, 207-8; Manfred Obermüller and Holger Hartenfels, 'Finanzsicherheiten' ['Financial Collateral Arrangements'] (2004) 11 Zeitschrift für Bank- und Kapitalmarktrecht 440-7, s 1.e; Pergamalis (n 9) 37.

22 Gullifer (n 8). Cf Bonfanti (n 18) 76-81, especially 81.

23 GSC (n 2) art 31(3)(f) and (g).

24 Kanda and others (n 8) 31-27.

25 Ibid 38-2, 38-9; Chun (n 8) 101. 
This opt-out provision gives Contracting States the opportunity: (i) to declare that Chapter V does not apply to natural persons or (ii) to specify in their declaration other categories of person that they do not wish to be subject to the regime of Chapter $\mathrm{V}$.

\section{Comparison}

The FCD and the GSC both take a broad personal scope as a starting point. Nonetheless, they define their scope differently. Whereas the FCD contains a detailed list of entities to which it applies, the GSC, in principle, has an unlimited personal scope. ${ }^{26}$ In order to fine-tune their scope, both instruments contain optout provisions. These opt-outs reflect concerns regarding possible undesirable consequences of the liberal approach taken by the two instruments.

The FCD does not apply to natural persons. ${ }^{27}$ The GSC, however, as a matter of principle applies to natural persons involved in financial collateral arrangements but leaves the exclusion of natural persons to the discretion of Contracting States (Article 38(2)(a)). As a consequence, in the event of accession to the GSC, ${ }^{28}$ the EU should exclude natural persons under the first option of Article 38(2) (a) of the GSC in order to ensure compatibility with the FCD. ${ }^{29}$

With respect to all other persons and entities, the FCD as a matter of principle has a broad scope, including financial market participants and a variety of nonfinancial entities. However, the personal scope of the FCD is limited to the categories explicitly referred to. In addition, Article 1(3) allows Member States to restrict the scope of the FCD to, in short, financial market participants. The

26 Keijser, Morton and Peeters (n 9) 2.15.

27 FCD (n 1) art 1(2)(d) and (e): 'a person[,] other than a natural person'.

28 GSC (n 2) art 40 covers signature, ratification, acceptance, approval, and accession. Ibid art 41(1) mentions signature, acceptance, approval, and accession. For ease of reference, this article only refers to accession.

29 GSC (n 2) art 41 determines that regional economic integration organizations, such as the EU, may accede to the GSC if they have competence over matters governed by the Convention. On the division of competences between such a regional organization and its Member States, see Kanda and others (n 8) 41-6-41-11. The competences of the EU and its Member States should be determined on the basis of arts 2-6 of the consolidated version of the Treaty on the Functioning of the European Union[2012] OJ C326/47 [TFEU] and Protocol (No 25) thereto on the exercise of shared competence. As to the competences of the EU and its Member States in relation to the GSC (a topic matter falling within the ambit of the TFEU art 4(2)), a distinction should be made between (i) the general part of the GSC, which area is not (yet) regulated in the EU, which, in principle, implies competence of the Member States (noting, however, that consultations on securities law legislation have been ongoing for a considerable period of time; see $<$ http://ec.europa.eu/internal_market/financial-markets/securities-law/index_en.htm > accessed 23 May 2014) and (ii) Chapter V of the GSC, the topic matter of which is also the subject of the FCD, which, in principle, implies competence of the EU. For further information, see, eg, Hans Van Loon and Andrea Schulz, 'The European Community and the Hague Conference on Private International Law' in Bernd Martenczuk and Servaas van Thiel (eds), Justice, Liberty, Security: New Challenges for EU External Relations (VUBPRESS, 2010) 257-99; Alan Rosas, 'The Status in EU Law of International Agreements Concluded by EU Member States' (2011) 34(5) Fordham International Law Journal 1304-45. 
second option of Article 38(2)(a) of the GSC allows the EU to bring the scope of the GSC in line with that of the FCD, by declaring which categories of persons it excludes from the in principle unlimited scope of Chapter V of the GSC. As a result, the two legal frameworks are generally compatible, even if neither has a fixed personal scope, since both allow Member or Contracting States a level of flexibility in the form of opt-out clauses. ${ }^{30}$

\section{Material scope: eligible collateral}

\section{Types of collateral: Financial Collateral Directive}

Article 1(4)(a) of the FCD determines which assets qualify as financial collateral. In particular, financial collateral may consist of cash, financial instruments, and credit claims. ${ }^{31}$ '[F] inancial instruments' are, in short, tradable securities, whether intermediated or not, including 'shares in companies and other securities equivalent to shares in companies and bonds and other forms of debt instruments if these are negotiable on the capital market and any other securities which are normally dealt in...' (Article 2(1)(e)). The broad scope of the FCD, including non-intermediated and different types of intermediated securities, follows from its general objective of liquidity, the absence of any limitation in the text of the FCD to intermediation or specific intermediated holding systems, and the fact that there is a great variety of holding systems in the EU Member States. ${ }^{32}$ ' [C] ash' refers to money credited to accounts in any currency or similar claims for the repayment of money (Article 2(1)(d)), while 'credit claims' are the pecuniary claims of a credit institution arising from a credit it has given in the form of a loan (Article 2(1)(o)).

The material scope of the FCD is therefore broad, but it can be restricted on the basis of two opt-out provisions. The first opt-out clause of Article 1(4)(b) of the FCD enables Member States to exclude 'the collateral provider's own shares, shares in affiliated undertakings... and shares in undertakings whose exclusive purpose is to own means of production that are essential for the collateral provider's business or to own real property'. In other words, it is possible to exclude securities issued by the collateral provider itself or by enterprises whose financial well-being is deemed to be closely linked to that of the collateral provider.

30 It should be noted that the FCD (n 1) recital (3) explicitly refers to only 'bilateral' financial collateral arrangements. Chun (n 8) 100 presumes a similar limitation in case of the GSC (n 2), but this does not follow from the text of the GSC or its official commentary.

31 Credit claims were introduced as possible collateral with the amendment of the FCD (n 1) in 2009. For a critical assessment of this amendment, see Bonfanti (n 18) 78-81, 87-90.

32 Bonfanti (n 18) 82; Roy Goode and others, Transnational Commercial Law: Text, Cases and Materials (Oxford University Press, 2007) 13.32. On different intermediated holding patterns, see Legal Certainty Group, Solutions to Legal Barriers Related to Post-Trading within the EU, Second Advice (2008), recommendation 4; Philipp Paech, 'Market Needs as Paradigm: Breaking up the Thinking on EU Securities Law' in Pierre-Henri Conac, Ulrich Segna and Luc Thévenoz (eds), Intermediated Securities: The Impact of the Geneva Securities Convention and the Future European Legislation (Cambridge University Press 2013) 22-64, 2.2.2. 
The purpose of this opt-out clause is to avoid facilitating the use of collateral, the value of which is closely linked to the financial situation of the collateral provider. If the collateral provider runs into financial difficulties, the value of such collateral may also decrease substantially, leaving the collateral taker with an unsecured exposure. $^{33}$

The second opt-out clause of Article 1(4)(c) of the FCD makes it possible to exclude credit claims from the list of eligible collateral, when the debtor is a consumer or a micro or small enterprise. ${ }^{34}$ As such, these debtors are given a special position. ${ }^{35}$ It is, however, not possible to exercise this opt-out to exclude credit claims involving consumers and micro or small enterprises when either the collateral provider or the collateral taker is one of the market participants referred to in Article 1(2)(b) of the FCD (namely, a central bank, the ECB, the BIS, an MDB, the IMF, or the EIB). ${ }^{36}$ Considerations such as the need for unobstructed execution of monetary policy thus prevail over those relating to the position of consumers and micro or small enterprises. ${ }^{37}$

\section{Types of collateral: Chapter $V$ of the Geneva Securities Convention}

According to Article 31(1) of the GSC, Chapter V applies to collateral agreements under which interests in intermediated securities are granted as collateral. ${ }^{38}$ This is in line with the focus of the GSC on intermediated securities. ${ }^{39}$ The GSC presupposes that every Contracting State has some kind of intermediated holding system, ${ }^{40}$ and it applies irrespective of the legal set-up of these systems. ${ }^{41}$ The focus on intermediated securities implies that the GSC does not apply to nonintermediated securities — that is, securities that are physically held by an investor

33 See Keijser, Financial Collateral Arrangements (n 8) II.8.2.2, which also briefly mentions the exclusion of shares in undertakings with the exclusive purpose of ownership of real property.

34 For the relevant definition of 'consumer', see Directive 2008/48/EC on credit agreements for consumers [2008] OJ L133/66 art 3(a); for the definitions of 'microenterprise' and 'small enterprise', see European Commission Recommendation 2003/361/EC [2003] OJ L124/36, Annex, arts 1 and 2.

35 For considerations of consumer protection in this context, see Directive 2009/44/EC (n 1) recital (6); Bonfanti (n 18) 78-81; European Commission, Proposal for a Directive of the European Parliament and of the Council amending Directive 98/26/EC on settlement finality in payment and securities settlement systems and Directive 2002/47/EC on financial collateral arrangements as regards linked systems and credit claims (17 March 2008) 1.3; HM Treasury, A Consultation on the Implementation of EU Directive 2009/44/EC on Settlement Finality and Financial Collateral Arrangements (August 2010) 2.21-2, and the subsequent Summary of Responses (December 2010) 2.15-6.

36 FCD (n 1) art 1(4)(c) in fine.

37 Cf Kentaro Tamura and Evangelos Tabakos, The Use Of Credit Claims as Collateral for Eurosystem Credit Operations, ECB Occasional Paper Series N148 (2013).

38 See also GSC (n 2) art 31(3)(b), (c), and (e).

39 This focus is already apparent from the full name of the Convention.

40 Kanda and others (n 8) 29-14.

41 Christophe Bernasconi and Thomas Keijser, 'The Hague and Geneva Securities Conventions: A Modern and Global Legal Regime for Intermediated Securities' (2012) 17(3) Uniform Law Review 549-60, 556-7; Kanda and others (n 8) Int-28-Int-30. 
in the form of certificates or registered with the issuer in the name of the investor. ${ }^{42}$ Likewise, cash is excluded, ${ }^{43}$ while credit claims arguably also fall outside of the scope of the GSC. ${ }^{44}$ The fact that it was decided to limit the GSC to intermediated securities does not mean, however, that its underlying principles (including those set out in Chapter V) cannot be applied to other assets.

Article 1(b) of the GSC defines 'intermediated securities' as 'securities credited to a securities account or rights or interests in securities resulting from the credit of securities to a securities account'. ${ }^{45}$ The definition of 'securities' in Article 1(a) of the GSC further limits the material scope of the GSC to 'shares, bonds or other financial instruments or financial assets (other than cash) which are capable of being credited to a securities account and of being acquired and disposed of in accordance with the provisions of this Convention'. The first criterion-that is, the capability of securities to be credited to a securities account-basically limits the GSC to securities that can be held and traded in the form of book entries. The second criterion - that is, the capability of securities to be acquired and disposed of in accordance with the GSC - is closely connected with the methods specified for that purpose in Article 11 (debit and credit) and Article 12 of the GSC (automatic perfection in favour of the relevant intermediary, designating entry, and control agreement). ${ }^{46}$ These two functional criteria thus determine which financial assets qualify as 'securities'. ${ }^{47}$

Since these two criteria are decisive, the GSC does not contain a list of financial instruments that qualify as collateral. As long as the two criteria are met, collateral may consist of bonds, other debt instruments, shares, other equity instruments, transferable units in collective investment schemes, securitized derivative instruments, and so on. ${ }^{48}$ Since no restrictive enumeration exists, the GSC also covers any financial instrument developed in the market in the future as long as it meets the requisite criteria. ${ }^{49}$

The official commentary on the GSC can be read so as to imply that Chapter V of the GSC applies, in principle, to 'both tradable and non-tradable securities' ${ }^{50}$ However, as discussed earlier in this section, Article 1(a) of the GSC requires that

42 Kanda and others (n 8) 1-19. See also Michel Deschamps, 'The Best Rules for Non-Intermediated Securities' in Thomas Keijser (ed), Transnational Securities Law (Oxford University Press 2014) $1-25$.

43 GSC (n 2) art 1(a); Kanda and others (n 8) 1-7.

44 Although neither the GSC (n 2) nor its official commentary say so explicitly, it is submitted that credit claims are outside the scope of the GSC, inasmuch as they do not fulfill the two functional criteria for qualifying as securities under the GSC (see the following paragraph).

45 Kanda and others (n 8) 1-15-1-20; Chun (n 8) 39 et seq.

46 See also GSC (n 2) art 13, which allows other methods under non-Convention law.

47 Kanda and others (n 8) 1-7-1-10.

48 Ibid 1-10.

49 Ibid 1-11; Chun (n 8) 39.

50 Kanda and others (n 8) 38-10. 
securities are 'capable of . . . being acquired and disposed of', which are aspects of tradability. In any case, Article 38(2)(b) of the GSC contains an opt-out clause that makes it possible to exclude intermediated securities that are not permitted to be traded on an exchange or regulated market from the material scope of Chapter V. ${ }^{51}$

\section{Types of collateral: comparison}

The FCD has a broader material scope than Chapter V of the GSC. Chapter V only applies to arrangements where the collateral consists of interests in intermediated securities, whereas the FCD also covers non-intermediated securities, credit claims, and cash provided as collateral. ${ }^{52}$ The two instruments also take a somewhat different approach in determining which securities fall within their scope. Article 2(1)(e) of the FCD contains an enumeration of 'financial instruments' that essentially covers a broad range of securities. The GSC formulates two functional criteria for 'shares, bonds or other financial instruments or financial assets' to fall within the scope of Chapter V: the capability of being credited to a securities account and of being acquired and disposed of in accordance with the provisions of the GSC. In substance, however, both instruments have a broad scope and are well capable of including new types of financial instruments or assets that may be developed in the market in the future.

An additional difference relates to tradability. The requirement of the FCD that financial instruments should be 'negotiable' or 'normally dealt in' on the capital market (Article 2(1)(e)) seems stricter than that of the GSC regarding the capability of being acquired and disposed of. Article 38(2)(b) of the GSC offers a solution, as it allows the EU to limit the scope of the GSC to securities that are 'permitted to be traded on an exchange or regulated market', but only insofar as the notion of exchange or regulated market' (GSC) coincides with that of 'capital market' (FCD).

The FCD also contains opt-out clauses that allow the exclusion of, in short, (i) the collateral provider's own shares or shares in undertakings that are economically linked to the collateral provider (Article 1(4)(b)) and (ii) credit claims, when their debtors are consumers or micro or small enterprises (Article 1(4)(c)). These 'opt-outs' are essentially different from that of Article 38(2)(b) of the GSC regarding non-tradable intermediated securities. On the one hand, the opt-outs of the FCD are tailored to categories of persons/entities (the collateral provider, economically related undertakings, consumers, and so on) and stem from policy considerations relating to the protection of the collateral taker from financial trouble involving the company of the collateral provider and to the position of consumers and minor enterprises. On the other hand, the opt-out of the GSC is

\footnotetext{
51 Ibid; Chun (n 8) 101. On the broad meaning of 'exchange or regulated market' under the GSC, see Kanda and others (n 8) 29-14.

52 Keijser, Morton and Peeters (n 9) 2.15.
} 
built on a specific function of securities - that is, their tradability - so as to respond to any policy considerations of the Contracting States in this respect. ${ }^{53}$

In relation to securities, this different approach leads to frictions. The shares issued by the company of the collateral provider or an economically related undertaking may very well be tradable securities. The GSC, however, does not allow them to be excluded from its scope, as is possible under the FCD. The opt-outs of the FCD and the GSC are therefore not compatible in this respect. $^{54}$

\section{Possession or control of collateral and evidential requirements}

Another limitation to the material scope of the FCD is that it only applies to collateral once it has been provided (Article 1(5), first subparagraph). 'Provision' means the delivery, transfer, holding, registration, or other designation of the collateral, resulting in the possession or control of the collateral taker or a person acting on the collateral taker's behalf (Article $2(2)$ of the FCD) ${ }^{55}$ In addition, the FCD contains requirements relating to evidence in the form of 'writing', including by electronic means and any other durable medium (Articles 1(5), 2(3), and 3 of the FCD). For evidential purposes, a book entry ('credit') is sufficient. The requirements relating to possession or control and evidence essentially limit the application of the liberal provisions of the FCD and, as such, balance market efficiency with the safety of the parties to collateral arrangements and the interests of third parties. ${ }^{56}$

Chapter V of the GSC does not contain requirements relating to the provision or delivery of collateral by way of possession or control and to evidence. ${ }^{57}$ Antony Zacaroli argues, however, that Articles 11 and 12 of the GSC (in Chapter III) fulfill a broadly similar function as the FCD's requirement of possession or control, because of the control implied in the different methods for acquisition and disposition set out in Articles 11 (debit and credit) and 12 (automatic perfection in favour of the relevant intermediary, designating entry, control agreement). ${ }^{58}$ Arguably, where book entries are involved (such as in the case of a debit/credit or a designating entry), a level of transparency (and thus evidence) is also guaranteed. However, the GSC contains no rules whatsoever on evidence concerning

53 Kanda and others (n 8) 38-10.

54 Chun (n 8) 101, n 343 also notes a discrepancy between the GSC (n 2) art 38(2)(b) and the FCD (n 1) art 1(4)(b).

55 On the problems this issue raises under English law, see Antony Zacaroli, 'Taking Security over Intermediated Securities: Chapter V of the UNIDROIT (Geneva) Convention on Intermediated Securities' in Louise Gullifer and Jennifer Payne (eds), Intermediated Securities: Legal Problems and Practical Issues (Hart Publishing 2010) 167-86.

56 FCD (n 1) recital (10). Cf Gullifer (n 8) 385-6; Keijser, Financial Collateral Arrangements (n 8) II.8.2.3.

57 It should be noted that where the FCD (n 1) uses the word 'provision', the GSC (n 2) often uses 'delivery' (or derivatives of these words). This article uses , 'provision' as a neutral term.

58 Zacaroli (n 55) 7.II, 7.IV, 7.V.A, especially 183-4. 
control agreements. ${ }^{59}$ Thus, the issues of possession/control and evidence are largely implicit in the GSC or left to non-Convention law.

The FCD and the GSC thus take a different approach in regard to the requirement that the collateral taker be in possession or control of the securities and to that of evidence. Whereas these issues are dealt with explicitly in the FCD, they are implicit in the GSC or left entirely to non-Convention law.

\section{Material scope: relevant obligations}

\section{Financial Collateral Directive}

Article 2(1)(f) of the FCD defines 'relevant financial obligations' as 'obligations which are secured by a financial collateral arrangement and which give a right to cash settlement and/or delivery of financial instruments'. Article 2(1)(f) also provides examples of different types of relevant obligations. The FCD covers relevant obligations: (i) irrespectively of when they were created, whether they are 'present or future, actual or contingent or prospective' (Article 2(1)(f)(i)), even if they are not known at the time of the arrangement (ratione temporis); (ii) owed by the collateral provider or by another (a third) person (Article 2(1)(f)(ii)) (ratione personae); (iii) which are of a specified class or kind arising periodically ('from time to time') (Article 2(1)(f)(iii)) (ratione materiae).

\section{Chapter $V$ of the Geneva Securities Convention}

Article 31(3)(d) of the GSC defines 'relevant obligations' as 'any existing, future or contingent obligations of a collateral provider or another person' and thus includes obligations irrespective of when they arose (ratione temporis) and makes it possible to secure obligations of third parties (ratione personae). ${ }^{60}$ Article $31(3)(d)$ contains no limitation, so it does not seem to exclude any category of relevant obligations. However, in order to respond to different national policies, Article 38(2)(c) leaves it to the discretion of Contracting States to declare that Chapter V of the GSC will not apply to collateral arrangements relating to specific categories of relevant obligations. These categories should be identified in the declaration. ${ }^{61}$

\section{Comparison}

Both the FCD and the GSC apply to any relevant obligations, without restriction as to the time when they were generated (whether present, actual, or existing; future or prospective; or contingent) and as to their debtors (including persons other than the collateral provider). Article 2(1)(f)(iii) of the FCD also explicitly includes relevant obligations of a specified class or kind arising from time to time,

59 Kanda and others (n 8) 12-10, 12-19, 12-30. For the deleted provision on 'Evidential requirements' (which referred the issue to non-Convention law), see UNIDRoIT 2008-CONF 11-Doc. 33, 9 (art 12).

60 Kanda and others (n 8) 31-23-31-24.

61 Ibid 31-25, 38-11. 
a category not mentioned in Article 31(3)(d) of the GSC. This textual difference does not cause any problem since both provisions are open to any kind of relevant obligation. $^{62}$

A substantive difference is that the FCD requires relevant obligations to be performed in a particular manner-that is, by 'cash settlement and/or delivery of financial instruments'. The FCD thus does not apply if the relevant obligations are to be performed in any other way. The GSC, however, does not contain such a limitation. ${ }^{63}$ In order to ensure consistency with the FCD, the EU should therefore, in case of accession, either limit the scope of the GSC by making use of the opt-out of Article 38(2)(c) of the GSC or broaden the scope of the FCD. ${ }^{64}$

\section{Right of use}

\section{Introduction}

Both the FCD and the GSC envisage the collateral taker's right to 'use' the collateral provided to it by the collateral provider under a security collateral arrangement (Article 5 of the FCD and Article 34 of the GSC). The device of a collateral taker's 'right of use' originates in the brokerage market in the USA, where brokers originally had the right to re-pledge the securities pledged by their clients, which was later broadened to a general right to sell, or otherwise dispose of, such securities. ${ }^{65}$ This development inspired the derivatives and securities-trading industry associations to lobby for the introduction of a right of use into the EU's FCD, ${ }^{66}$ after which the device also found its way into Chapter V of the GSC. The main considerations in introducing the right of use were reduced funding costs, the flexible use of securities portfolios, and enhanced liquidity. ${ }^{67}$

Article 2(1)(m) of the FCD defines a 'right of use' as 'the right of the collateral taker to use and dispose of financial collateral provided under a security financial collateral arrangement as the owner of it in accordance with the terms of the security financial collateral arrangement'. Article 34(1) of the GSC defines the 'right of use' as the collateral taker's 'right to use and dispose of the collateral

62 Cf Chun (n 8) 143.

63 Keijser, Morton and Peeters (n 9) 2.15.

64 Kanda and others (n 8) example 38-1.

65 Christian Johnson, 'Derivatives and Rehypothecation Failure: It's 3:00 p.m., Do You Know Where Your Collateral Is?' (1997) 39 Arizona Law Review 949-1001; Kenneth Kettering, 'Repledge and Pre-Default Sale of Securities Collateral under Revised Art 9' (1999) 74(3) Chicago-Kent Law Review 1109-55; Kenneth Kettering, 'Repledge Deconstructed' (1999) 61(1) University of Pittsburgh Law Review 45-239.

66 Erica Johansson, 'Reuse of Financial Collateral Revisited' in Louise Gullifer and Jennifer Payne (eds), Intermediated Securities: Legal Problems and Practical Issues (Hart Publishing 2010) 151-65, 152.

67 FCD (n 1) recitals (3) and (19); Johansson (n 66) 153; Kanda and others (n 8) 34-1; Keijser, Morton and Peeters (n 9) 2.29. 
securities as if it were the owner of them' ${ }^{68}$ Essentially, these definitions boil down to a general right of disposal. ${ }^{69}$ The right of use enables the collateral taker to sell the collateral, lend it, pledge it to a third party, or dispose of it in any other way, even if the applicable national legal regime does not traditionally grant the collateral taker such rights. ${ }^{70}$

The combination of a security interest with a general right of disposal is not easy to square with the core principles of security law in a range of jurisdictions. ${ }^{71}$ For example, upon exercise of the right of use by the collateral taker, the collateral provider often will no longer have any proprietary claim (right in rem) with respect to the original collateral and can no longer redeem it. Exercise of the right of use may also be at odds with the collateral taker's duty of good care or custody in relation to the assets that it has disposed of. The collateral provider will therefore, in any case if title is transferred, be left with a mere contractual claim. ${ }^{72}$

In order to achieve at least some equilibrium, the right of use, which is generally favourable to the collateral taker, is available only if the collateral provider has consented to it. Article 5(1) of the FCD determines that the right of use can be exercised only ' $\mathrm{i}$ ]f and to the extent that the terms of a security financial collateral arrangement so provide'. Article 34 of the GSC sets out the same requirement in almost the same words. ${ }^{73}$

\section{Equivalent and replacement collateral}

Apart from the requirement of the collateral provider's consent, another way to mitigate the consequences of the right of use for the collateral provider is that the collateral taker, upon exercise of this right, must provide 'equivalent' or 'replacement' collateral to the collateral provider. In this connection, the following issues will be discussed: (i) the relevant definitions and terminology; (ii) the category of 'other assets'; (iii) proprietary substitution; (iv) the applicable timeframes; and (v) the available alternatives.

Article 5(2) of the FCD obliges the collateral taker, upon exercise of the right of use, to transfer 'equivalent collateral to replace the original financial collateral' to the collateral provider. Article 2(1)(i) of the FCD defines 'equivalent collateral' as: (i) in relation to cash, 'a payment of the same amount and in the same currency'; and (ii) in relation to financial instruments:

71 Erica Johansson, Property Rights in Investment Securities and the Doctrine of Specificity (Springer 2009) 15-18; Keijser, Morton and Peeters (n 9) 2.30 (with further references). On the related qualification of the right of use as 'pignus irregulare' under, for example, Danish, German, Greek, and Italian law, see Bonfanti (n 18) 104-11; Cecilia Carrara, Pietro Fulvio and Joseph Nivaro, Report on a 'Right of Use' for Collateral Takers and Custodians, edited by Thomas Keijser (2003); Keijser, Financial Collateral Arrangements (n 8) IV.4.6; Obermüller and Hartenfels (n 21) 446; Pergamalis (n 9) 36, n 23.

72 Johansson (n 66) 153; Kanda and others (n 8) 34-1; Keijser, Morton and Peeters (n 9) 2.50.

73 Kanda and others (n 8) 34-1, 34-13. 
financial instruments of the same issuer or debtor, forming part of the same issue or class and of the same nominal amount, currency and description or, where a financial collateral arrangement provides for the transfer of other assets following the occurrence of any event relating to or affecting any financial instruments provided as financial collateral, those other assets.

Likewise, Article 34(2) of the GSC obliges the collateral taker, upon exercise of the right of use, to deliver 'replacement collateral' to the collateral provider, which may consist of: (i) 'equivalent collateral'- that is, 'securities of the same description as collateral securities ${ }^{74}$ - or (ii) other assets, 'if the security collateral agreement provides for the delivery of other assets following the occurrence of any event relating to or affecting any securities delivered as collateral'. ${ }^{75}$

The terminology used in these definitions is slightly different. Whereas under the FCD 'equivalent collateral' essentially includes both assets with the same characteristics as the original collateral and other assets, the GSC uses the term 'replacement collateral' to refer to both 'equivalent collateral' (that is, in short, securities with the same characteristics as the securities originally provided as collateral) and other assets. Basically, 'equivalent collateral' under the FCD therefore corresponds with what is 'replacement collateral' under the GSC.

With respect to the category of 'other assets', both the FCD and the GSC allow the provision of assets with other characteristics than the 'original collateral' if certain events (in particular, corporate events affecting the securities, such as a merger or a take-over concerning the issuing company) take place and if the collateral agreement provides for it. The FCD allows the provision of such 'other assets' in relation to financial instruments, but it does not specify what these other assets may be. The GSC does so neither, but its official commentary clarifies that 'other assets' may be not only 'securities issued by the merged or acquiring company but also, for example, government bonds or cash'. ${ }^{76}$ It is therefore not necessarily the case that 'Article 34(2) [of the GSC] goes further than Article 5 of the Financial Collateral Directive in that the Geneva Securities Convention gives the parties the right to agree to deliver collateral of a different type than the collateral originally provided'. ${ }^{77}$

Both instruments also contain a rule of 'proprietary substitution'. Article 5(3) of the FCD requires that the equivalent collateral is subject to the same terms of the collateral agreement as the 'original collateral', and is treated as having been provided at the same time as the original collateral was provided. The same approach is followed in Article 34(3) of the GSC. ${ }^{78}$ In both cases, the 'proprietary substitution' is favourable to the collateral taker, which is deemed to have had a

${ }^{74}$ GSC (n 2) art 31(3)(i) defines 'equivalent collateral'; art 1(j) defines 'of the same description'.

75 On GSC (n 2) arts 1(j), 31(3)(i), 34(2), see Kanda and others (n 8) 1-48-1-49, 31-31, 34-3, 34-14.

76 Ibid 34-3, 34-14. Cf the broader interpretation, including even 'vessels' in the category of 'other assets', rejected by the delegation of the United Kingdom in UNIDROIT 2009-CONF 11/2-Doc. 10 paras 33-5.

77 Johansson (n 66) 160.

78 Kanda and others (n 8) 34-4. 
security interest in the equivalent or replacement collateral on the same terms as those referring to the original collateral and with retroactive force. By excluding the possibility of the equivalent or replacement collateral being presented as new, the collateral taker need fear no adverse legal consequences, especially concerning the priority of security interests. ${ }^{79}$

In regard to the period in which the equivalent or replacement collateral should be provided, the collateral taker under the FCD can transfer equivalent collateral from the date it exercised its right of use until (and including) the due date for the performance of the relevant financial obligations (Article 5(2), first subparagraph). Article 34(2) of the GSC, however, provides that the delivery of replacement collateral should take place after the moment when the right of use was exercised but 'not later than the discharge of the relevant obligations'. Arguably, this latter phrase allows the collateral taker, depending on the moment of such discharge, to fulfill its obligations not only on the due date of performance but also earlier, or even later, than the due date ${ }^{80}$ Whereas the FCD thus refers to the contractually agreed 'due date', the GSC takes the moment of factual discharge by the collateral provider as the moment of reference. ${ }^{81}$ The collateral taker can therefore wait until the collateral provider takes action. ${ }^{82}$

In addition to the collateral taker's obligation to provide equivalent or replacement collateral in a timely manner, the FCD and the GSC set out a number of alternative options. The FCD contains three such options. ${ }^{83}$ Article 5(2), second subparagraph, of the FCD essentially mentions two of these options. Strictly speaking, the repetition in this subparagraph of the collateral taker's statutory obligation to provide equivalent collateral is superfluous (as it is already mentioned in Article 5(2), first subparagraph) and, thus, not an 'alternative'. The only alternatives that the second subparagraph of Article 5(2) really adds are the set-off of the value of the equivalent collateral against, or application thereof in discharge of, the relevant financial obligations on the due date. ${ }^{84}$ Both alternatives should have been agreed upon in the security financial collateral arrangement. Set-off and discharge under Article 5(2), concerning equivalent collateral and without any requirement of the occurrence of an enforcement event, should be distinguished from Article 4 of the FCD-the general enforcement provision of the Directive-which also mentions set-off and discharge, but only as enforcement mechanisms in respect of collateral provided earlier, including financial instruments and credit claims (in these two cases, after their sale or appropriation) as

79 Ibid 34-16.

80 Ibid 34-3, 34-14.

81 Johansson (n 66) 160.

82 See also Chun (n 8) 143.

83 Johansson (n 71) 15 mentions set-off, discharge, and close-out netting.

84 Somewhat surprisingly, these alternatives are available only to the collateral taker (ie, the party that did not yet fulfill its obligations) but not to the collateral provider. On the collateral taker-oriented approach of the FCD, see the text at and the sources mentioned in note 8 in this article. 
well as cash. Elsewhere, in Articles 5(5) and 7, the FCD envisages the third alternative-that is, close-out netting ${ }^{85}$ upon the occurrence of an enforcement event $^{86}$ (such as the non-performance of contractual obligations or insolvency). ${ }^{87}$

Generally, the GSC is more elegantly drafted, as it concentrates all enforcement issues in a single provision (Article 33). Article 33(1) of the GSC only relates to set-off or discharge in connection with a sale or appropriation, upon the occurrence of an enforcement event, of collateral delivered earlier. ${ }^{88}$ The most important remedy under the GSC in a situation where an obligation for the delivery of 'equivalent collateral ${ }^{89}$ remains outstanding is, therefore, close-out netting upon the occurrence of an enforcement event (Article 33(1)(b) and (2))..$^{90}$

As to the options that are available to the parties if equivalent or replacement collateral is not provided in a timely fashion, the FCD and the GSC thus both envisage close-out netting but approach set-off or application in discharge of the relevant obligations differently. Whereas both instruments envisage such set-off or discharge as an enforcement mechanism in relation to collateral already provided, only the FCD mentions set-off and discharge in connection with equivalent collateral specifically (and without requiring the occurrence of an enforcement event).

\section{Post-crisis developments}

To the extent that a set-off, an application in discharge of the relevant obligations, or close-out netting are available, neither of the parties will face any shortfall. However, situations of under- or over-collateralization - that is, situations where there is a discrepancy between the value of the collateral provided and the secured liabilities - imply a level of credit risk that may prove harmful in insolvency. A degree of under- or over-collateralization may exist as of the outset of a transaction or arise in the course of a transaction due to price fluctuations in the market that are not corrected by the provision of margin collateral. ${ }^{91}$

The recent financial crisis showed instances of enormous discrepancies between the collateral provided and the secured obligations. This was one of the triggers of a still ongoing debate on private law and/or regulatory restrictions

85 FCD (n 1) art 2(1)(n) defines 'close-out netting provision'. On close-out netting, see also section $\mathrm{VI}$ in this article.

86 FCD (n 1) art 2(1)(l) defines 'enforcement event'.

87 Under the FCD (n 1) arts 5(5) and 7, close-out netting is available to both collateral taker and collateral provider. Cf note 84 in this article.

88 GSC (n 2) art 31(3)(h) defines 'enforcement event' in almost the same way as FCD (n 1) art 2(1)(1).

89 Whereas GSC (n 2) art 34(2) correctly refers to the broader notion of 'replacement collateral', the reference in art 33(2) to 'equivalent collateral' is too narrow. Kanda and others (n 8) 34-15, however, correctly refer to 'replacement collateral'.

90 GSC (n 2) art 31(3)(j) defines 'close-out netting provision'. On close-out netting, see also section VI in this article.

91 Johansson (n 71) 16; Kanda and others (n 8) 34-15; Keijser, Financial Collateral Arrangements (n 8) IV.1.3.1; Keijser, Morton and Peeters (n 9) 2.22, n 39. 
on the right of use. ${ }^{92}$ The European legislator has imposed several such restrictions ${ }^{93}$ and could amend the FCD. ${ }^{94}$ Whether any such restrictions are compatible with the GSC should in any case be tested against the tenth recital of the Preamble of the GSC, which leaves the power to regulate, supervise, or oversee to Contracting States unless it 'would contravene the provisions of this Convention'. One of these provisions is Article 31(2) of the GSC, which sets a minimum level of protection for collateral takers. ${ }^{95}$ The criteria of the test are rather unclear, however. Does a quantitative restriction on the right of use contravene the provisions of the GSC, for instance? Or is the criterion rather that the qualitative 'core' of the right of use should not be infringed upon (for example, when it is abolished or when the collateral taker cannot dispose outright but can only vest further security interests)? ${ }^{96}$

\section{Close-out netting}

\section{The liberal approach of the Financial Collateral Directive and the Geneva Securities Convention}

Generally, both the FCD and the GSC take a liberal approach to the enforcement of rights in relation to financial collateral upon the occurrence of an enforcement

92 Basel Committee on Banking Supervision (BCBS) and Board of the International Organization of Securities Commissions, Margin Requirements for Non-Centrally Cleared Derivatives (September 2013) Element 5, 18-21; Financial Stability Board (FSB), Strengthening Oversight and Regulation of Shadow Banking: Policy Framework for Addressing Shadow Banking Risks in Securities Lending and Repos (29 August 2013) Recommendations 7 and 8; Keijser, Morton and Peeters (n 9) 2.B. See also the reactions on the FSB document from, for example, the French Banking Federation (28 November 2013) I.3; The Luxembourg Bankers' Association (28 November 2013) 5-6; and the Managed Funds Association (28 November 2013) 6, all available at <http://www.financialstabilityboard.org/publications/c_131220.htm> accessed 26 June 2014.

93 For examples of the European patchwork regarding this issue that appeared since the financial crisis, see Directive 2011/61/EU on alternative investment fund managers [2011] OJ L174/1, recital (49), arts 14(3), 15(4), 21(10), last paragraph, 21(11)(d)(iv), 23(1)(a), 23(1)(o), 23(5)(a), 24(4); Directive 2014/65/EU on markets in financial instruments (recast) [2014] OJ L173/349, recital (52), arts 16(8), 16(10); Regulation (EU) 648/2012 on over-the-counter derivatives, central counterparties, and trade repositories [2012] OJ L201/1, arts 39(8), 52(1), last paragraph, 53(2); Proposal for a Regulation on reporting and transparency of securities financing transactions COM(2014) 40 final, 2014/0017 (COD) (29 January 2014) Explanatory Memorandum, especially 3.4.4, and arts 15, 20(1)(b). Cf Keijser, Morton and Peeters (n 9) nn $48,102,106$.

94 See European Commission, Legislation on Legal Certainty of Securities Holding and Dispositions: Tenth Discussion Paper of the Services of the Directorate-General Internal Market and Services, Sixth Meeting of the Member States Working Group (16 October 2012) and the critical assessment of this paper by Madeleine Yates and Gerald Montagu, The Law of Global Custody ( ${ }^{\text {th }}$ edn, Bloomsbury Professional 2013) 7.190.

95 For further information on Article 31(2) GSC and the interests of collateral provider and collateral taker, see the sources mentioned in note 8 in this article.

96 For some guidance, see Kanda and others (n 8) 34-2. On restrictions on the right of use in the USA, see Charles Mooney, 'The Truth about Shortfall of Intermediated Securities: Perspectives under the Geneva Securities Convention, United States Law, and the Draft European Securities Law Directive' in Pierre-Henri Conac, Ulrich Segna and Luc Thévenoz (eds), Intermediated Securities: The Impact of the Geneva Securities Convention and the Future European Legislation (Cambridge University Press 2013) 160-92. The US delegation negotiating and agreeing to the adoption of the GSC presumably thought that the approach in the USA is compatible with the GSC. Cf the debate on regulatory restrictions on close-out netting in section VI.3 in this article. 
event. ${ }^{97}$ Article 4 of the FCD and Article 33 of the GSC both allow different methods of enforcement, including sale and appropriation. Customary formal requirements, such as prior notice, approval by a court or another independent party, and realization by public auction or in any other prescribed manner are prohibited. ${ }^{98}$ In addition, the commencement or continuation of insolvency proceedings that affect the collateral provider or the collateral taker should not influence the operation of enforcement. ${ }^{99}$ The resulting rapid and non-formalistic enforcement procedures are intended to contribute to cost reduction, liquidity, mitigation of contagion effects in insolvency, reduction of systemic risk, and, thereby, to financial stability generally. ${ }^{100}$

For comparable reasons, the FCD and the GSC apply the same liberal approach to close-out netting arrangements. ${ }^{101}$ Close-out netting is an enforcement mechanism that is typically applied in connection with derivatives, repurchase and securities lending agreements, and other securities financing arrangements. ${ }^{102}$ Close-out netting generally consists of three elements or stages: early termination upon an enforcement event (either automatically or by one of the parties), valuation of closed-out transactions or obligations, and netting to determine the final net obligation of one of the parties. ${ }^{103}$ Close-out netting, if enforceable, allows market participants to reduce their outstanding mutual obligations to a net exposure that is often only a fraction of their gross exposures.

The FCD defines 'close-out netting provision' in Article 2(1)(n). The core provision of the FCD on close-out netting is Article 7, while this device is also dealt with in Article 5(5) (in the context of the right of use) and Article 6(2) (in the context of obligations to transfer equivalent collateral in the case of title transfers). Article 7 sanctions close-out netting in general, making the specific rules of Article 5(5) and Article 6(2) essentially superfluous. ${ }^{104}$

97 ' $[E]$ nforcement event' is defined in FCD (n 1) art 2(1)(l) and GSC (n 2) art 31(3)(h), see also nn 86,88 in this article.

98 FCD (n 1) arts 4(4) and 7(2); GSC (n 2) art 33(3)(a).

99 FCD (n 1) arts 4(5) and 7(1)(a); GSC (n 2) art 33(3)(b).

100 FCD (n 1) recital (17); Gullifer (n 8) 396-9. For some counter-arguments, see also Keijser, Financial Collateral Arrangements (n 8) V. For the optional safeguard of 'commercial reasonableness', see FCD (n 1) art 4(6) and GSC (n 2) art 35.

101 FCD (n 1) recital (14); Ole Böger, 'Close-Out Netting Provisions in Private International Law and International Insolvency Law (Part I)’ (2013) 18(2) Uniform Law Review 232-61, A, D.II; Unidroit, Principles on the Operation of Close-Out Netting Provisions (2013) Introduction, 5-6, 9. For a critical analysis of the arguments in favour of close-out netting, see Marcel Peeters, 'On Close-Out Netting' in Thomas Keijser (ed), Transnational Securities Law (Oxford University Press 2014) 55-86.

102 See, eg, the International Swaps and Derivatives Association Master Agreement (2002) ss 5 and 6; Global Master Repurchase Agreement (2011) para 10; Global Master Securities Lending Agreement (2010) paras 10 and 11; European Master Agreement (2004) ss 6 and 7.

103 Peeters (n 101) 3.10. See also Böger (n 101) B.I. Note, however, that different types of close-out netting can be distinguished; see Peeters (n 101) 3.11-22.

104 See also section V.2 in this article, especially the text at nn 85-7. 
The GSC defines 'close-out netting provision' in Article 31(3)(j). ${ }^{105}$ The substance of close-out netting is addressed in Articles 33(1)(b), 33(2), and 33(3) of the GSC. Article 33(1)(b) and 33(2) both sanction close-out netting in both title transfer and security collateral agreements. ${ }^{106}$ Strictly speaking, the general rule of Article 33(1)(b) makes the specific rule of Article 33(2) redundant. ${ }^{107}$

Both legal instruments coincide in that they abolish formal requirements (including prior notice, approval, and a prescribed manner of enforcement) in the case of the operation of close-out netting, ${ }^{108}$ while it must also be enforceable in insolvency. ${ }^{109}$ There are, nonetheless, some (drafting) differences that should be taken into account. For example: (i) the definition of 'close-out netting provision' in Article 2(1)(n) of the FCD mentions statutory rules, whereas the definition in Article 31(3)(j) of the GSC is limited to agreements between the parties; (ii) Article 2(1)(n) of the FCD does not discriminate between collateral provider and collateral taker, whereas Article 31(3)(j) of the GSC contains a phrase 'or may at the election of the collateral taker occur' (emphasis added); ${ }^{110}$ (iii) Article $4(4)(d)$ of the FCD abolishes any formal requirement that 'any additional time period must have elapsed', whereas no such abolition features in Article 33(3)(a) of the GSC; (iv) Article 7(1)(b) of the FCD determines that a close-out netting provision can take effect 'notwithstanding any purported assignment, judicial or other attachment or other disposition of or in respect of such rights', ${ }^{111}$ an issue that is not addressed in the GSC. Sections VI.2 and VI.3 in this article focus on two further (possible) discrepancies between the FCD and the GSC in relation to close-out netting, notably relating to the role of national law and regulatory developments inspired by the recent financial crisis.

\section{The role of national law}

The FCD generally protects the enforceability of close-out netting. However, the FCD does not offer certainty in all respects, as national law still plays an important role when determining if and under what conditions close-out netting can take effect. Due to the fact that close-out netting confers a considerable advantage on the creditor that can invoke it, but, at the same time, results in the disappearance of assets to which this creditor's counterparty and its other creditors might have been entitled, national law restrictions (for example, concerning the reciprocity of

\footnotetext{
105 GSC (n 2) art 31(3)(j) defines 'close-out netting provision' broadly, so as to cover different national legal approaches and contractual arrangements. See Kanda and others (n 8) 31-30, 33-16.

106 Kanda and others (n 8) 33-2, 33-16-33-18; Charles Mooney and Guy Morton, 'Harmonizing Insolvency Law for Intermediated Securities: The Way Forward' in Thomas Keijser (ed), Transnational Securities Law (Oxford University Press 2014) 193-239, n 51.

107 See also section V.2 in this article, especially text at note 90.

108 FCD (n 1) art 7(2) in conjunction with art 4(4); GSC (n 2) art 33(3)(a).

109 FCD (n 1) art 7(1)(a) in conjunction with art 4(5); GSC (n 2) art 33(3)(b).

110 Bonfanti (n 18) 113 argues that close-out netting should be available to both the collateral provider and the collateral taker. On the debate of whether rights are available to the collateral

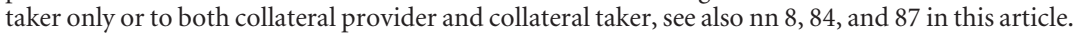

111 Grammatically, it is unclear what 'such rights' refers to.
} 
claims or knowledge of the party invoking a set-off of its counterparty's insolvency) come into play to determine how the interests of different groups of creditors are balanced. ${ }^{112}$

The text of the GSC, however, does not mention any continued role for national law requirements. The official commentary on the GSC only states in general terms that Article 33 intends 'to eliminate obstacles to enforcement that might arise under national legislation', which approach also applies to close-out netting. ${ }^{113}$ The official commentary does not, however, unequivocally preclude a continued role of national law in the context of close-out netting. It therefore remains rather unclear whether national requirements such as those that are allowed under the FCD are prohibited under the GSC. If this is the case, the FCD and the GSC are incompatible on this point.

\section{Post-crisis developments}

The recent financial crisis has led to a wide-ranging policy debate on the resolution of financial institutions. ${ }^{114}$ In the EU, one of the results of that debate is Directive 2014/59/EU establishing a framework for the recovery and resolution of credit institutions and investment firms (Recovery and Resolution Directive or RRD), ${ }^{115}$ which, among other things, envisages an amendment of the FCD that essentially boils down to a limitation of the FCD's liberal enforcement regime. ${ }^{116}$

In particular, the RRD envisages the invalidation of ipso facto clauses-that is, provisions "which make "the fact itself" of the commencement of resolution measures an event of default and thus a ground for termination of the relevant contract $^{\prime 117}$ (Article 68) as well as the right of resolution authorities temporarily to suspend (or 'stay') the termination rights of the failing institution's counterparty (Article 71). ${ }^{118}$ These measures give the resolution authority the necessary time to put into practice various resolution tools and prevent the immediate termination of large numbers of contracts, leading to further instability. ${ }^{119}$ These measures, however, are not compatible with Article 2(1)(l) of the FCD, insofar as it allows ipso facto clauses as enforcement events under the FCD, or with Articles 2(1)(n) and 4-7 of the FCD, where these require that enforcement provisions can take effect in accordance with their terms as agreed by the parties

112 FCD (n 1) recital (15); Keijser, Financial Collateral Arrangements (n 8) V.3.

113 Kanda and others (n 8) 33-10, 33-19, 33-23.

114 See, for example, BCBS, Report and Recommendations of the Cross-Border Bank Resolution Group (March 2010); FSB, Key Attributes of Effective Resolution Regimes for Financial Institutions (October 2011). The FSB's Key Attributes are currently being implemented, see <http://www. financialstabilityboard.org > accessed 24 June 2014.

115 Directive 2014/59/EU establishing a framework for the recovery and resolution of credit institutions and investment firms [2014] OJ L173/190.

116 Ibid art 118, which relates to FCD (n 1) arts 4 to 7.

117 Keijser, Morton and Peeters (n 9) 2.72.

118 RRD (n 115) recital (94); Keijser, Morton and Peeters (n 9) 2.C, especially 2.71-4.

119 Cf BCBS (n 114) Recommendation 9, 40-2; FSB (n 114) s 4 and Annex IV. 
(without taking into account any discretion of the regulatory authorities). Article 118 of the RRD addresses these discrepancies by amending the FCD.

The GSC does not contain any provisions corresponding to the recommendations of the $\mathrm{BCBS}$ or the $\mathrm{FSB}^{120}$ or comparable to the provisions of the RRD, and is therefore arguably not in line with post-crisis developments. As mentioned in the context of possible restrictions on the right of use (section V.3 in this article), the tenth recital of the Preamble of the GSC leaves regulation, supervision, and oversight to Contracting States in as far as they do not contravene the provisions of the GSC. Arguably, restrictions on enforcement, such as the non-recognition of ipso facto clauses as enforcement events and the power given to regulatory authorities to temporarily suspend termination rights, contravene core elements of Articles 31(3)(h), (j), and 33 of the GSC. ${ }^{121}$

In 2013, Unidroit enacted the Principles on the Operation of Close-Out Netting Provisions (Principles), ${ }^{122}$ which (at least partly) take the impact of the financial crisis into account. ${ }^{123}$ Principle 8 , like the $\mathrm{RRD}$, recognizes the possibility of a stay or any other measures in relation to the operation of a close-out netting provision in the context of the resolution of a financial institution. Although both the GSC and the Principles are UNIDROIT projects, they take a different approach regarding the admissibility of restrictions on enforcement. The GSC should arguably be aligned with the policy approach underlying the recommendations of the BCBS and the FSB, the RRD, and the Principles. ${ }^{124}$

\section{Protection of margin maintenance and substitution arrangements}

\section{Introduction}

In light of the special nature of financial collateral (see section I in this article), both Article 8 of the FCD and Articles 36 and 37 of the GSC provide a level of protection to the parties to a collateral arrangement, particularly in the case of insolvency. This section focuses on such protection afforded to margin maintenance and substitution arrangements, which the parties to a collateral arrangement commonly use to maintain an economic balance and a level of flexibility in the course of a transaction. ${ }^{125}$ The economic balance is reached by both parties agreeing to the provision of margin collateral in order to address exposures arising due to, in particular, price fluctuations in relation to collateral provided earlier or the relevant obligations. ${ }^{126}$ The level of flexibility is reached by

\footnotetext{
120 See the sources mentioned in note 114 in this article.

121 Keijser, Morton and Peeters (n 9) 2.76.

122 Principles on the Operation of Close-Out Netting Provisions < http://www.unidroit.org/instruments/capital-markets/netting > accessed 21 May 2014.

123 Peeters (n 101) 3.64.

124 Likewise, see Keijser, Morton and Peeters (n 9) 2.76, 2.80.

125 FCD (n 1) recitals (5), (16).

126 Keijser, Financial Collateral Arrangements (n 8) II.4.3, II.8.5.
} 
'substitution' clauses that allow a collateral provider to substitute or exchange collateral provided earlier for collateral with different characteristics but of substantially the same value. ${ }^{127}$

Both the FCD and the GSC protect the provision of collateral under margin maintenance and substitution arrangements from any retroactive force of insolvency and when such collateral is provided after the relevant obligations are incurred-that is, the two instruments afford protection from 'timing claw back rules' or 'automatic avoidance rules' ${ }^{128}$ This includes protection from socalled 'zero hour rules', on the basis of which a declaration of insolvency has retroactive effect to the beginning of the day on which it is issued. ${ }^{129}$ For the FCD, the protection from automatic avoidance rules follows from Article 8(3). It should, however, be noted that the FCD provides no protection in other instances, such as avoidance or fraud against creditors. ${ }^{130}$ For example, an 'actio pauliana', which makes it possible to void transactions entered into by an insolvent entity with particular creditors with the purpose of making assets unavailable to the general creditors, may still be exercised. ${ }^{131}$ Likewise, the protection of Article 36 of the GSC is limited to automatic avoidance rules and does not extend to other circumstances. ${ }^{132}$

\section{Margin: protection 'both ways'?}

With respect to the provision of margin, the preferred interpretation of Article $8(3)$ (a) of the FCD is that it protects both the provision of excess 'financial collateral' by a collateral taker to a collateral provider (notably when the value of collateral provided earlier has risen in value or the value of the relevant obligations has decreased) as well as the provision of 'additional financial collateral' by a collateral provider to a collateral taker, in addition to collateral provided earlier (when the value of that collateral is no longer sufficient to cover the relevant obligations). Strictly speaking, this interpretation is not in line with Article 2(2) of the FCD, which, as discussed in section III.4 in this article, limits the concept of 'provision' to delivery etc. in the direction of the collateral taker (or a person acting on its behalf). However, if 'financial collateral' in Article 8(3)(a) is not interpreted as excess but as initial financial collateral, there is an overlap with the protection envisaged in Article $8(1)$ of the FCD. In addition, such an

127 Ibid II.4.4, II.8.6.

128 Hereinafter, the term 'automatic avoidance rules' will be used.

129 Kanda and others (n 8) 36-3; Keijser, Financial Collateral Arrangements (n 8) V.4; Charles Mooney and Hideki Kanda, 'Core Issues under the UnIDroIT (Geneva) Convention on Intermediated Securities: Views from the United States and Japan' in Louise Gullifer and Jennifer Payne (eds), Intermediated Securities: Legal Problems and Practical Issues (Hart Publishing 2010) 69-130, 128.

130 FCD (n 1) recital (16) and art 8(4).

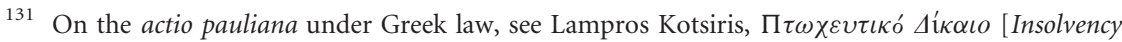
Law] (Sakkoulas 2008) 231-2.

132 Kanda and others (n 8) 36-3, 36-28. On the protection of margin maintenance and substitution arrangements after the commencement of insolvency proceedings, see section VIII in this article. 
interpretation would lead to the undesirable situation that only certain margin transfers are protected, and others not. The protection of Article 8(3)(a) arguably thus works both ways and covers collateral provided in the course of a transaction by both the collateral provider and the collateral taker.

The wording of the GSC regarding the delivery of margin is equally unfortunate. Article 36(1)(a) only refers to the delivery of 'additional collateral securities' but not to the return of excess collateral. This wording might be argued to imply that only additional collateral is protected, whereas excess collateral is not. Likewise, the 'top-up' terminology in the heading of Article 36 suggests a limitation to the protection of additional collateral. In line herewith, Article 36 takes the viewpoint of the collateral taker: Article 36(1)(a)(ii) only mentions the credit risk of the collateral taker but not that of the collateral provider and Article 36(1), in fine, refers to the 'commencement of an insolvency proceeding in relation to the collateral provider' (emphasis added) (but does not take that of the collateral taker into account). ${ }^{133}$ Nonetheless, the official commentary on the GSC makes it clear that Article 36 applies both ways: 'Top-up refers to the situation where one of the parties to a collateral agreement delivers additional collateral or returns excess collateral in order to ensure that the outstanding obligations of the parties are balanced'. ${ }^{134}$

Since both the FCD and the GSC thus arguably protect (or should protect) the provision of both additional and excess financial collateral, their scope of protection coincides.

\section{Margin: triggers of protection}

At least three different 'triggers' for the protection of the provision of additional or excess margin can be distinguished. First, Article 8(3)(a) of the FCD protects the provision of margin in case of 'changes in the value of the financial collateral or in the amount of the relevant financial obligations' ${ }^{135}$ Likewise, Article $36(1)(a)(i)$ of the GSC provides protection in case of 'changes in the value of the collateral delivered under the collateral agreement or in the amount of the relevant obligations'. ${ }^{136}$ Protection is thus afforded in case of margin that is provided to cover an exposure of one of the parties that has arisen due to a change in the market prices of either the collateral or the relevant obligations. ${ }^{137}$ The FCD only protects the provision of margin in case of such price fluctuations

133 FCD (n 1) art 8(3) does not contain a similar reference to the collateral provider.

134 Kanda and others (n 8) 36-1.

135 Keijser, Financial Collateral Arrangements (n 8) II.8.5.

136 Kanda and others (n 8) 36-13-36-17.

137 Ibid 36-13 state that 'the value at the time when [the original] collateral was delivered must be compared to the value of that collateral at the time where the top-up obligation is implemented'. It would seem more accurate to say that the value at the time of implementation of the top-up (better: margin; cf section VII.2 in this article) obligation should be compared to the value at the latest preceding date at which the top-up (better: margin) obligation was implemented (or, in the absence of such a date, to the value of the original collateral when it was delivered). 
in the market, whereas the GSC also offers protection in two other circumstances. $^{138}$

Second, Article 36(1)(a)(ii) of the GSC also protects the delivery of margin securities where an increase takes place 'in the credit risk incurred by the collateral taker as determined by reference to objective criteria relating to the creditworthiness, financial performance or financial condition of the collateral provider or other person by whom the relevant obligations are owed'. In this case, the object of estimation is not the collateral or the relevant obligations (asset-related focus) but, rather, the entity of the collateral provider or other debtor of the relevant obligations (subject-related focus). ${ }^{139}$

The approach set out in Article 36(1)(a)(ii) of the GSC poses challenges from an insolvency law perspective. A deterioration of the financial situation of an entity may be an omen of its insolvency. Any protection granted in this context to a particular group of creditors could thus have an impact on the position of all of the other creditors and on the principle of their equal treatment (paritas creditorum). On the basis of such considerations, the protection provided by the FCD does not extend to margin provided as a result of a change in the financial position of the parties to a collateral agreement. ${ }^{140}$ For the same reasons, Article 36(2) of the GSC allows Contracting States to opt out of Article $36(1)(a)(i i)$ and not to provide protection in case of a deteriorating financial situation. $^{141}$

Against this background, it seems preferable for the EU to make use of this optout clause in the GSC, so that the regimes of the GSC and the FCD are comparable. However, even if the opt-out of Article 36(2) is exercised, there remains a friction as to the protection offered by the GSC and the FCD in regard to collateral, the value of which is directly linked to the collateral provider's financial position (for example, when the collateral provider is a company and has provided its own shares as collateral). The delivery of such collateral may be protected under Article 36(1)(a)(i) of the GSC, even if the opt-out of Article 36(2) of the GSC is exercised. ${ }^{142}$ Under the FCD, however, such protection is not available where Member States have entirely excluded this type of collateral on the basis of the opt-out of Article 1(4)(b) of the FCD. ${ }^{143}$

Finally, Article 36(a)(iii) of the GSC provides protection to margin securities delivered 'in any other circumstances specified in the collateral agreement', to the

138 Kanda and others (n 8) 36-12.

139 Ibid 36-18-36-19. On the collateral taker-oriented wording of the GSC (n 2) art 36(1), see section VII.2 in this article.

140 Keijser, Financial Collateral Arrangements (n 8) II.8.5.

141 Kanda and others (n 8) 36-20; Mooney and Kanda (n 129) 128. As the protection of GSC (n 2) art 36 is limited to automatic avoidance rules (see section VII.1 in this article), the reference in Kanda and others (n 8) 36-20 to 'avoidance or preference in fraud of other creditors' does not seem entirely appropriate, as there is no protection anyway in such cases.

142 Kanda and others (n 8) 36-14.

143 See also section III.1 in this article. 
extent permitted by non-Convention law. ${ }^{144}$ The protection against automatic avoidance rules under the GSC can therefore be extended to more cases according to the free will of the parties, while the only limitation to this party autonomy is the non-Convention law. ${ }^{145}$ The GSC thus moves the burden of 'watchdog' to Contracting States.

The FCD and the GSC therefore differ as to the content of the triggers of the protection of margin collateral. The FCD includes only one such trigger, in contrast to the three elaborated in the GSC. Whereas both legal instruments provide a level of protection to margin provided in connection with changes in the value of the financial collateral or in the amount of the relevant financial obligations, the GSC also allows the financial situation of the collateral provider and cases agreed by the parties as triggers of protection. ${ }^{146}$

\section{Substitution}

Article 8(3) of the FCD provides protection against automatic avoidance rules not only in case of a margin maintenance arrangement but also where the parties to a financial collateral arrangement have agreed on 'a right to withdraw financial collateral on providing, by way of substitution or exchange, financial collateral of substantially the same value'. Likewise, Article 36(1)(b) of the GSC provides protection where the parties have agreed on 'a right to withdraw collateral securities or other assets on delivering collateral securities or other assets of substantially the same value'. ${ }^{147}$ This provision of the GSC thus includes 'other assets', whereas 'financial collateral' under the FCD only refers to cash, financial instruments, and credit claims. ${ }^{148}$ In substance, however, the protection of substitution arrangements under the FCD and the GSC coincides.

\section{Treatment after the commencement of insolvency proceedings}

\section{Financial Collateral Directive}

Article $8(1)$ and (3) of the FCD aim at the protection of financial collateral arrangements and the provision of financial collateral thereunder, before the commencement of insolvency proceedings. ${ }^{149}$ Article $8(2)$ of the FCD provides similar protection after the commencement of insolvency proceedings. More specifically, Article $8(2)$ provides protection 'on the day of, but after the moment of the commencement of, winding-up procedures or reorganisation

144 For the definition of 'non-Convention law', see GSC (n 2) art 1(m).

145 Kanda and others (n 8) 36-21.

146 See also Chun (n 8) 143-4.

147 Kanda and others (n 8) 36-22-36-26.

148 FCD (n 1) art 1(4) in conjunction with art 2(1)(d), (e), (o); see also sections III.1 and V.2 in this article.

149 In light of the abolishment of zero hour rules, the moments of declaration and commencement of insolvency proceedings will coincide. See text at note 129 in this article. 
measures', 'if the collateral taker can prove that he was not aware, nor should have been aware' of such a commencement.

The scope of Article 8(2) is somewhat ambiguous. It applies where 'a financial collateral arrangement or a relevant financial obligation has come into existence, or financial collateral has been provided'. It is not entirely clear whether 'financial collateral' here comprises only initial collateral or also excess and additional (in the case of a margin maintenance arrangement) as well as replacement (in case of a substitution arrangement) collateral. Article 8(3), which distinguishes between (excess) 'financial collateral', 'additional financial collateral', and 'replacement collateral' currently does not provide protection after the commencement of insolvency proceedings. The most appropriate interpretation is to apply Article $8(2)$ to all aspects of financial collateral arrangements, because application to only some aspects would result in a rather erratic scope and impair the practical value of the provision. Ideally, the wording of Articles 8(2) and 8(3) is further coordinated.

Moreover, Article 8(2) covers only collateral takers that were not aware, and should not have been aware, of the commencement of insolvency proceedings. Article $8(2)$ uses the concept of 'awareness', but does not use related concepts such as 'good faith' or 'innocent acquisition'. ${ }^{150}$ The content of 'awareness' should be determined under the law of each Member State, with special attention paid to the special nature of securities markets where, on the one hand, transactions may take place within milliseconds but where, on the other hand, information on the (potential) insolvency of market participants will also generally be available immediately. ${ }^{151}$

These special characteristics of, and the certainty needed in, the securities markets were considerations when the EU legislator granted protection after the commencement of insolvency proceedings. However, from a general insolvency law perspective, such protection is fairly controversial, since the insolvency law in many jurisdictions as a matter of principle 'freezes' the insolvent estate and the position of its creditors at the moment the insolvency proceedings commence. As a result of Article 8(2), assets may, however, disappear from the insolvent estate even after this moment, to the benefit of collateral takers and, thus, to the detriment of the general creditors. ${ }^{152}$

\section{Chapter $V$ of the Geneva Securities Convention}

Chapter V of the GSC contains two provisions, Articles 36 and 37, concerning the validity of financial collateral arrangements in case of the commencement of insolvency proceedings. Both provisions relate to the period before this commencement. Article 36 protects the delivery of collateral under margin

\footnotetext{
150 Note, however, that the conflict of laws provision of FCD (n 1) art 9(2)(c) refers to 'good faith acquisition'.

151 Keijser, Financial Collateral Arrangements (n 8) V.4.3.3.a. Cf Kanda and others (n 8) 17-9-17-10.

152 On the risk of abuse, see Keijser, Financial Collateral Arrangements (n 8) V.4.3.3.b.
} 
maintenance and substitution arrangements if it takes place 'during a prescribed period before, or on the day of but before' the commencement of the collateral provider's insolvency proceedings. Article 37 provides comparable protection in other cases that are outside the scope of Article 36, namely the conclusion of collateral agreements or the delivery of (initial) collateral securities. ${ }^{153}$ Neither of these two provisions says anything about the period after the commencement of insolvency proceedings. The proper interpretation of this silence is that the situation after the commencement of insolvency proceedings is simply left untouched and is left to the discretion of each Contracting State. ${ }^{154}$

If a Contracting State were to introduce protection after the commencement of insolvency proceedings comparable to that of Article 8(2) of the FCD, Article 18 of the GSC could serve as a source of inspiration to incorporate the FCD's standard of 'unawareness'. ${ }^{155}$ Article 18 provides protection in case of acquisitions by an 'innocent person' - that is, any acquirer unless it 'actually knows or ought to know' about the relevant facts. ${ }^{156}$ Article 17 (b) and (c) of the GSC provides guidance on this knowledge standard and includes a reference to the characteristics and requirements of securities markets'. ${ }^{157}$

\section{Comparison}

Both the FCD and the GSC provide protection for collateral arrangements before the commencement of insolvency proceedings. However, the legal instruments do not coincide with respect to the treatment of collateral after this moment. In this case, Article 8(2) of the FCD explicitly provides protection if the collateral taker was not aware, nor should have been aware, of the commencement of the collateral taker's insolvency proceedings. The GSC, on the contrary, does not envisage such protection but allows Contracting States to provide for it. In case the EU accedes to Chapter V of the GSC, care should be taken to ensure that the notions of 'awareness' (Article 8(2) of the FCD), 'good faith' (Article 9(2)(c) of the FCD), and 'innocence' (Articles 17 and 18 of the GSC) are compatible.

\footnotetext{
153 Kanda and others (n 8) 36-27, 37-1-37-6.

154 Ibid 31-17, example 31-1, 36-27, 37-4.

155 There is, however, no direct link between GSC (n 2) arts 36 and 37 (Chapter V) and art 18 (Chapter III). In addition, the ninth recital of the Preamble of the GSC states that 'this Convention is not intended to harmonize or otherwise affect insolvency law except to the extent necessary to provide for the effectiveness of rights and interests governed by this Convention'.

156 The GSC (n 2) uses the notion of 'innocent acquisition' instead of 'good faith' because the latter concept is linked to traditional property law rules for tangible assets and cannot easily be applied to book-entry securities. See Thomas Keijser and Miriam Parmentier, 'The Geneva Securities Convention: The Debates of the Diplomatic Conference' (2010) 25(4) Butterworths Journal of International Banking and Financial Law 230-2, 232.

157 Kanda and others (n 8) 17-8-17-20.
} 


\section{Conclusion}

The FCD is often more detailed than Chapter V of the GSC, which adopts a more broad-brush approach in order to accommodate a wide range of legal systems. Nonetheless, the two instruments take a similar approach in relation to most topics and are generally compatible. There are, however, a few instances in which they are not, partly because of the recent financial crisis, while a number of drafting glitches also deserve attention.

With respect to personal scope, both instruments cover financial market participants, such as banks and other financial institutions, while also allowing transactions between these participants and non-financial entities to be covered. In contrast to the FCD, the GSC also envisages the inclusion of natural persons as well as transactions in which both participants are non-financial entities. Regarding the types of eligible collateral, the FCD has a wider material scope due to the fact that, apart from intermediated securities, which are also covered by the GSC, non-intermediated securities, cash, and credit claims also qualify as collateral. The opt-out provisions of the two instruments regarding eligible collateral have a different focus and are not compatible. Concerning the obligations secured by a collateral arrangement, the material scope of the GSC is broader, since it contains no limitation on the kind of relevant obligations, like the requirement in the FCD that they should give a right to cash settlement and/or delivery of securities.

Both instruments envisage a general right of the collateral taker to dispose of collateral (a 'right of use') and oblige the collateral taker to provide equivalent or replacement collateral upon the exercise of this right. Compared to the FCD, the GSC allows a more flexible time frame for the fulfilment of this obligation but offers fewer alternative solutions such as set-off or discharge. Whether the private law or regulatory restrictions on the right of use that are currently the subject of debate are compatible with the current set-up of the GSC is a matter that should be carefully assessed.

Both the FCD and the GSC allow the application of rapid and non-formalistic enforcement mechanisms upon the occurrence of an enforcement event, including 'close-out netting'. Generally, the two instruments ensure that close-out netting arrangements are enforceable, even in the insolvency of one of the parties. The FCD, however, explicitly leaves some room for national law, an issue on which the GSC is entirely silent. In addition, the financial crisis has inspired the amendment of the FCD by the RRD, with the purpose of introducing regulatory restrictions on the exercise of close-out netting rights so as to facilitate the recovery or restructuring of failing financial institutions. This new approach is also enshrined in Principle 8 of the UniDroit Principles on the Operation of CloseOut Netting Provisions. However, the GSC is not (yet) in tune with this new regulatory approach.

Both legal instruments provide protection to margin maintenance and substitution arrangements against automatic avoidance rules, notably in insolvency. Whereas both the FCD and the GSC provide protection in case of margin 
provided in light of changes in market value, the GSC provides two additional situations in which margin maintenance arrangements are protected-that is, a worsening financial position of the collateral provider and other events agreed upon between the parties. In addition, the FCD explicitly makes it possible to uphold the validity of collateral arrangements not only before but also after (but on the same day as) the commencement of insolvency proceedings, if the collateral taker is not, nor should have been, aware of the commencement. The GSC does not provide for such protection after the commencement of insolvency but leaves the issue up to each Contracting State.

The FCD and Chapter V of the GSC have simplified the mechanisms for the provision and enforcement of financial collateral. These simplifications were expected to make credit available at a lower cost, enhance liquidity, and reduce systemic risk and, as such, to contribute to a flourishing economy. Unfortunately, the recent financial crisis revealed the repercussions of an overly liberal legal framework. Although the amendment of the FCD (in 2009) and the adoption of Chapter V of the GSC (also in 2009) took place in the aftermath of the financial crisis, their (amended) content is more in tune with pre-crisis circumstances. In particular, it would seem that some parameters were not sufficiently taken into consideration, such as irresponsible behaviour by collateral takers, the protection of economic actors with a weak bargaining position, and a variety of factors influencing systemic stability. The financial crisis has thus resulted in a vivid (new or revived) debate on the desirable private law and regulatory framework regarding financial collateral, including such matters as restrictions of the personal scope of the FCD and the GSC, limits on the right of use, and the treatment of close-out netting. The debate on these and comparable issues and opportunities for 'technical' improvements may well inspire (further) changes to the framework of the FCD and GSC. 